\title{
ethic@ \\ ETHICAL RECOMMENDATIONS FOR MUSIC THERAPY IN NEUROREHABILITATION: IMPURE A PRIORI FOUNDATIONS AND TRANSPERSONAL HOLISM
}

\author{
RECOMENDAÇÕES ÉTICAS PARA MUSICOTERAPIA NA \\ NEUROREABILITAÇÃO: FUNDAMENTOS A PRIORI IMPUROS E \\ HOLISMO TRANSPESSOAL
}

\author{
TRISTAN GUILLERMO TORRIANI ${ }^{1}$ \\ (UNICAMP/Brasil)
}

\begin{abstract}
RESUMO
A musicoterapia tem se mostrado útil no tratamento de uma ampla gama de distúrbios, mesmo que muitas vezes em apenas uma função auxiliar. Sua utilização para pacientes que necessitam de reabilitação neurológica é bastante recente e sua eficácia tem sido avaliada qualitativa e quantitativamente. Os praticantes devem passar por um treinamento rigoroso para obter a certificação e devem ser capazes de combinar um alto nível de habilidades terapêuticas e artísticas. Como membros de equipes multidisciplinares, espera-se que os musicoterapeutas (1) justifiquem sua participação empregando os métodos mais eficazes à sua disposição; (2) adaptem ou mesmo criem material musical mais adequado às necessidades dos pacientes; e (3) se esforcem para uma compreensão teórica do que sua intervenção está tentando realizar. Estas recomendações emergem de realidades concretas das quais não poderíamos tomar conhecimento a priori. Uma tentativa de fundamentá-las post hoc em uma concepção universal abstrata da dignidade humana realizada na razão prática de Kant, por mais atrativa que possa parecer filosoficamente, está repleta de lacunas lógicas (non sequiturs) e circularidade (Rorty). Os conceitos morais devem antes ser entendidos como critérios impuros a priori de julgamento moral adquiridos e negociados através da socialização linguística (Herder, Piaget, Vygotsky, Wittgenstein, Habermas). A construção coletiva de uma futura neuroética faz sentido como um apelo humanitário (a Humanität de Herder) seguindo a prática jurisprudencial do direito comum inglês, ao contrário da imposição de cima para baixo de um código civil global. No que diz respeito à terapia musical, ela provavelmente permanecerá inserida no contexto antropológico moral dos idiomas, culturas e tradições locais, embora com algumas influências estrangeiras causadas pelo intercâmbio internacional.
\end{abstract}

Palavras-chave: Musicoterapia; Neuroética; Neuroreabilitação; A priori impuro; Metafísica Moral.

\footnotetext{
ABSTRACT

Music therapy has been proven useful in the treatment of a wide range of disorders, even if often in only an auxiliary role. Its use for patients requiring neurological rehabilitation is rather recent and its effectiveness has been assessed
} 
both qualitatively and quantitatively. Practitioners must undergo rigorous training to obtain certification and must be able to combine a high level of therapeutic and artistic skills. As members of multidisciplinary teams, music therapists are expected to (1) justify their participation by employing the most effective methods at their disposal; (2) adapt or even create musical material best suited to patients' needs; and (3) strive for a theoretical understanding of what their intervention is trying accomplish. These recommendations emerge from concrete realities that we could not take cognizance of purely a priori. An attempt to ground them post hoc in an abstract universal conception of human dignity realized in Kant's practical reason, attractive as that might seem philosophically, is ridden with logical gaps (non-sequiturs) and circularity (Rorty). Moral concepts ought rather to be understood as impure a priori criteria for moral judgment acquired and negotiated through linguistic socialization (Herder, Piaget, Vygotsky, Wittgenstein, Habermas). The collective construction of a future neuroethics makes sense as a humanitarian plea (Herder's Humanität) following the jurisprudential practice of English common law rather than the top-down imposition of a global civil code. In so far as music therapy is concerned, it will most likely remain embedded in the moral anthropological context of local languages, cultures and traditions, albeit with some foreign influences caused by international exchange.

Keywords: Music Therapy; Neuroethics; Neurorehabilitation; Impure a priori; Moral Metaphysics.

\section{Introduction}

Music Therapy (MT) has shown itself to be remarkably effective in the rehabilitation of brain injuries. This raises three research questions: (1) What ethical recommendations can we identify in MT used for neurorehabilitation? (2) Can some kind of a priori foundation (Kant) be provided for these recommendations? (3) If so, how can an impure a priori moral metaphysics (Herder), contribute to a more holistic and transpersonal approach (R. Steiner, M. P. Hall, C. G. Jung)?

\section{Identifying Ethical Demands and Recommendations in Music Therapy for Neurorehabilitation}

Since the 1990s, the literature on the applications of MT to neurorehabilitation has grown considerably due to the possibilities created by several brain imaging techniques. From a bioethical perspective, the requirements placed upon MT practitioners are not unusual for health and social care workers, but turn out to be intriguing because the history of music as a means of healing is little known (Horden 2000). Upon examining the literature, three demands stood out as particularly important. 
Music therapists must demonstrate the utility of their approach

The first demand is that MT practitioners convince the multidisciplinary medical team they are part of that their contribution to the patients' rehabilitation justifies their presence. In particular, it is important to clarify in exactly what does MT add value to the treatment. As Magee (1999) points out, neurorehabilitation is expensive and the patients' recovery takes precedence over all else. Music therapists must let go of any artistic narcissism they may yet retain from their musical training. Fortunately for MT, after trauma the brain must explore new pathways and it turns out that music's holistic and pre-verbal character can indeed stimulate neuroplasticity and functional retraining. Moreover, the general public is receptive to claims that music can have a soothing and healing effect (Decker-Voigt and Bruhn 1994). Gilbertson and Aldridge (2008) express concern that researchers have focussed too much on MT's effects on the recovery of functional ability because it is easier to measure and demonstrate with controlled quantitative methods. This leads to a neglect of the more holistic benefits music may bring to the patients' quality of life. They also note a lack coherence and unity in MT approaches worldwide. Thaut and Hömberg (2014) distinguish between patient-centered and discipline-centered approaches to neurorehabilitation. In the latter, patients must go through sessions with different professionals who deal with specific after-effects and make uneven progress. In the former, the patients' recovery is made to be central and specialists work as a multidisciplinary team in a coordinated effort.

Music therapists must use suitable music to respect the patient's condition and spiritual identity

The second demand is that although MT may happen in groups, each patient should receive individualized attention (Gilbertson and Aldridge 2008). For example, patients are likely to respond better to musical styles or genres of their preference. Music therapists have a wide range of alternatives at their disposal: live or recorded music; improvised or composed; vocal or instrumental; accompanied or unaccompanied; monophonic or polyphonic; familiar or new; natural or artificial, and many other possibilities involving timbre, pitch range, tempo, rhythm, percussion. Much depends on the ailment. Sacks (2018) explains that while for Parkinson's patients recorded music may be enough activate their motor system, aphasic patients require much closer attention from the therapist so that they can gradually recover more complex speech skills. Gilbertson and Aldridge (2008) note that neural damage often causes patients to 
undergo what amounts to a change of identity. Depending on the severity of the brain injury, rehabilitation may be only partial when the damage sustained is irreversible. This means that therapist and patient shall have to collaborate in the construction of a new lifeworld (Habermas) or view of life with disabilities. In doing this, MT can be conducted in different ways. Plahl (2008) distinguishes between passive, active, functional or combined MT. In passive MT, the patient only listens. In active MT, the patient gets involved in some musical activity. Functional MT focuses on recovery of specific skills. Combined MT uses all these modalities according to the patients' needs. She also references Herbert Bruhn's distinctions concerning the center of therapeutic intervention: the conflict-centered approach uses music to bring relief, the experience-centered approach explores subjective states, and the exercise-centered approach focuses on achieving skills and movements. Plahl explains that the application of MT is regulated by two principles: the iso-principle and the level-principle. The iso-principle directs the therapist to accommodate the music to the patient's condition. Davis, Thaut and Gfeller (2008) describe the iso-principle as a first stage, in which a connection is established with the patient by matching their mood. In the next stage, which Plahl calls the level-principle, the music is subtly changed to help the patient reach the physiological and emotional state that is being aimed for. As a part of this attention to individual needs, Aldridge (2000) stresses that if the health care systems are to be really pluralistic, it should be possible for patients and staff to include the spiritual or transpersonal dimension in their healing work if they want to. This concern for spirituality in the patients' lifeworld can be seen, as Helen M. Tyler (Horden 2000) notes, in the Nordoff and Robbins (NRMT) approach, which was influenced by Rudolf Steiner's Anthroposophy.

\section{Theory as an Epistemic and Educational Duty}

The third demand is that music therapists do not neglect their theoretical education and strive to offer their patients the best informed treatment they can. Barbara Wheeler (Baker, Tamplin and Kennelly 2006, 9) perfectly describes the typical situation found in so many faculties of applied sciences:

Some people working in this and other areas wish that they could just do the work - they are impatient with theoretical matters and why things need to be done as they are done. In the case of people with brain injuries, they may wonder why they have to understand the working of the brain or, indeed, 
may find it all so complicated that they wonder if it is possible to understand (Baker, Tamplin and Kennelly 2006, 9).

Decker-Voigt and Bruhn (1994) agree that in spite of their shared thematic interests, MT has not sought sufficient theoretical grounding in the Psychology of Music, where research is clearly divided in Methodenforschung (research of methods) and Wirkungsforschung (research of effects). Piaget (1970) admits that historically Psychology itself, much like Medicine, was compelled to intervene in practical situations without proper experimental testing and theoretical understanding. In his view, applications and theory could be mutually beneficial. However, he warns against the temptation to narrow our understanding of problems to find immediate practical solutions. Bunge (1999) stresses the importance of distinguishing at least three lines of work: (a) research, conducted theoretically and empirically by basic scientists; (b) technology, which employs theories to develop tools to change the world; and (c) service, which actually puts those tools into practice. He advises against confusing the means and ends of each type. On the one hand, it is preposterous to demand that theoreticians do service. On the other hand, he is critical of Nursing Theory in so far as it overtheorizes a service (Bunge 2012). In his discussion of Music Therapy Theory (MTT), Aigen (2014) acknowledges that the three main indigenous models for MT (analytical music therapy, AMT; guided imagery and music, GIM; and Nordoff-Robbins music therapy, NRMT) came about as clinical techniques lacking theory to guide procedures and protocols. He points out that theory takes on a greater role in quantitative research than it does in qualitative work because the latter is more phenomenological. Aigen acknowledges Michael Thaut's rational scientific mediating model (RSMM) as the main representative of foundationalism in MTT that follows current standards of medical research. RSMM focuses on clarifying processes by which music affects nonmusical functions the patient needs to heal. It proposes that MT practice should be grounded on a proper understanding of music's effect on cognition, emotions and sensorial motricity. Aigen admits that RSMM could provide a common standard for the diverse field of MT, but fears that it could end up restricting patients' access to alternative clinical practices and theories as well. Aigen advocates a Pragmatic approach instead in which theory is developed as post hoc explanations of clinical practice. He argues, much like Bunge, that a service should prioritize attention to the patients' need over regulating practice according to theoretical dictates. Bonde (2015) agrees with Aigen on the soundness of Pragmatism but defends a "selfexperience based music therapy" that requires the therapist to develop a thorough knowledge of several theoretical perspectives. All in all, this third 
demand on the need for theory is less clear cut than the previous two. If MT is essentially a service, then a proper balance between theory and practice will prioritize the latter without neglecting the former altogether.

General Recommendations: F. K. Harford, NIH \& WHO

Extensive experience with music therapy interventions in a clinical context, particularly after the First World War, has led to the formulation of general recommendations, some of which are listed below.

Frederick Kill Harford (1832-1906) was a British Canon who founded the Guild of St. Cecilia, one of the first organizations devoted to music therapy. According to Helen M. Tyler (Horden 2000, 378):

The precepts which can be inferred from Harford's venture may be summarized as follows:

1. That music has the power to affect patients in physical or emotional distress.

2. That music is effective as a form of treatment, alongside medical intervention.

3. That there needs to be co-operation between the medical and musical professionals.

4. That training is essential before undertaking the work.

5. That the efficacy of the work must be established by systematic evaluation and the publication of research findings (Horden 2000, 378).

Gilbertson and Aldridge $(2008,20)$ provide a list of recommendations by a 1999 NIH Development Panel for the treatment of patients with traumatic brain injury (TBI):

1. Rehabilitation services should be matched to the needs, strengths, and capacities of each person with TBI and modified as those needs change over time.

2. Rehabilitation programmes for persons with moderate or severe TBI should be interdisciplinary and comprehensive.

3. Rehabilitation of persons with TBI should include cognitive and behavioural assessment and intervention (Aldridge 2008, 20).

They also enumerate the WHO's main stated concerns on rehabilitation: 
1. Rehabilitation, as a rule, does not lead to profit.

2. The aims of rehabilitation should not be oriented to economical factors.

3. Rehabilitation is a social strategy, that aims at a fair and equal society.

4. Rehabilitation is a measure of our willingness to cooperate with the poorest, the most dependent and the underprivileged in our society (Aldridge 2008, 20).

Neuroethics as Ethical Theory, not Neuroscience

Before we go on to explore foundational issues concerning these recommendations, it is important to clarify that to avoid what we consider to be naturalistic circularity, we shall not compound the two accepted meanings of the term 'neuroethics' (Roskies 2016). As is well known, on the one hand, it may mean "the neuroscience of ethics." This approach requires scientific research that is beyond the purview of this paper, and shall hence be ignored. On the other hand, the ethics of neuroscience acknowledges that the systematic quest for true, empirically objective and formally consistent knowledge is pursued within a social and moral context upon which we ought to reflect. This is a legitimate task to which philosophers or ethicists can and should contribute substantially at the conceptual level.

\section{On the Intersubjectivist A Priori Grounding of these Recommendations}

Almost three hundred years after Kant's birth, it may seem pointless to attempt to ground in pure a priori practical reason the recommendations we saw above concerning music therapy. However, a wholesale abandonment of a concern for foundations seriously compromises the possibility of negotiating disagreements in reasoned argumentation. Once this is done, the only options left open are polemics, deception and violence. Although Foucault's concern about biopower is perfectly legitimate, Habermas' advocacy of intersubjective reason embodied in communicative action, despite problems in its technical details, is indispensable to maintain philosophical discourse and a more humane democratic culture. As Piaget showed (and common sense has always known), the desire for reasons, justifications and explanations is deeply rooted in human nature and is manifest already in childhood.

Since the 1980s, several authors, following hints from Wittgenstein's later aphorisms, have sought to build foundationalist proposals that vary from stronger (K.-O. Apel \& Habermas) to weaker (Peter Hacker, Arno Ros). 
Some authors, such as Paul Ricoeur, Richard Rorty, Charles Taylor and Alasdair MacIntyre veered towards narrative argumentation, in which deductive consistency is inextricably intertwined with historical context. Despite their significant differences, for the purposes of this article they shall be grouped under the label of 'Intersubjectivists' because of the importance they lay on interpersonal understanding (Crossley 1996) as opposed to inner exploration of those we shall call 'Intrasubjectivists' in the last section, who are more concerned with intraindividual processes (Tesser and Schwartz 2001). In the following, we shall contrast idealcommunicative rationalism (Habermas) to anarchic non-foundationalism (Rorty) and settle for the intermediate postion of weak foundationalism (Hacker \& Ros).

\section{Ideal-Communicative Rationalism (Habermas)}

At one end of the spectrum, Habermas (1990) represents a renewed Kantian quasi-foundationalism expressed in the linguistic paradigm of the Wittgensteinian dispensation. As Nielsen (1993) points out, although Habermas officially renounces to any metaphysical foundation, he still tries to preserve as much as possible to a concept of reason and Philosophy that is inherited from the great German Idealist tradition. His first objection to non-cognitivist (emotivist, imperativist and prescriptivist) approaches is that although moral argumentation may indeed often fail, in principle it remains possible to achieve agreement and that the attitude of seeking mutual understanding is in itself valuable as a way to peacefully negotiate differences. His second argument is that the strict, formal logical sense of truth as a propositional value should be widened to encompass what he calls truthfulness. For this to work, value claims have to be expressed within the scope of rhetoric, not of logic or dialectics alone. On this point, the solution suggested by weak foundationalism is to speak of a speech-act such as a plea, for example, instead of a true claim about a value such as the good. The concept (or criterion) of meaning (including its existential or ontological sense) is more appropriate than just truth as a propositional value. However, even if practical discourse could occur in an ideal communicative situation, it is not clear that it could provide unbroken deductive arguments grounded in a universal pure practical reason as Kant imagined. An ultimate foundation (Letztbegründung) that K.-O. Apel and Habermas propose depends on performative contradiction, which is liable to misinterpretation by the opponent. Unfortunately, Kant's pure practical reason must be accepted beforehand and cannot be demonstrated by itself 
without dogmatism or circularity (Rorty). In sum, Habermas' discourse ethics takes a step in the right direction but becomes technically problematic because its claims are too strong.

\section{Non-Foundationalism (Rorty)}

At the other end of the spectrum, Richard Rorty (1999) overplays the fragility created by the Wittgensteinian linguistic turn and ends up with a non-foundationalist post-philosophy (Calcaterra 2019). He mobilizes several interlocked arguments: he flat out denies any representational use of language or mind; any extra-linguistic access to knowledge; any superior language game or "meta-vocabulary"; and any nonhuman language ("world-language"). Nielsen (1993) agrees with Rorty and sees in Habermas a failed attempt to perpetuate an unnecessary unity of reason reminiscent of Kant and Hegel. However, this post-philosophical approach throws out the baby with the bathwater. Just because a "meta-vocabulary" should not be imposed dogmatically upon others does not mean that it could not become a source of symbolic meaning for a life with strong values (Taylor 2012). On a less negative and skeptical note, Rorty proposes a concept of historical contingency neither of will nor of reason, just a Humean change of habit; he expresses an inclination towards narratives and utopias; he advocates endless personal freedom, instead of a quest for a pre-existent transcendent truth. While this may appear liberating, it has been pointed out that the loss of strong values related to Wittgensteinian intersubjectivist rejection of a "meta-vocabulary" has the downside of producing nihilistic indifference and anomie (Joas 2000). Paradoxically, Rorty's postphilosophical non-foundationalism ends up behaving pretty much like the positivism it opposes, in that it precludes depth and meaning at an intraindividual level.

Weak Foundationalism (Hacker, Ros): "Necessity within Legitimacy" or Internal vs. External Justification

Between the two poles briefly mentioned above, some Wittgensteinian intersubjectivists have sought to explore more carefully the possibilities opened up by the social dimension of language. Hardy-Vallée (2012) equates this somewhat exageratedly with a radical nominalism. Instead of appealing, as the strong foundationalists do, to a Kantian universal pure a priori reason that is essentially pre-given to humanity as an external criterion to regulate language, weak foundationalists regard the a priori as a framework that emerges from linguistic exchange to generate legitimate conceptual alternatives. Once these frameworks are established, 
as in elementary arithmetic and geometry, logical necessity obtains within the formal system, making internal justification possible. Rorty's expatiations about contingency fail to properly address this distinction between internal and external justification (Ros 1990). Internal justification is stronger because it is supported deductively by the logical system's assumptions. Thus, basic mathematics education becomes an anthropological or cross-cultural universal once it is adopted worldwide. External justification, however, is weaker because it depends on persuasion and is holistic, as it tries to propose a whole classificatory system as being a legitimate way to interpret phenomena according to our cognitive and other needs. This is where Rorty's claims about contingency can acquire some relevance, provided his defeatist attitude is reconsidered.

Weak foundationalists recognize that justification, whether internal or external, occur empirically, as we communicate. For this reason, the a priori cannot be pure, but must be considered impure because the form of empirical concepts accommodates to perceptual content. For example, the construction of a concept of a dog will depend on what instances were available to be subsumed under it. For Kant, the pure a priori was made up of fixed, sealed off, and possibly innate, categories of the understanding that carried with them the triadic features of transcendental objectivity, necessity, and universality.

Piaget's naturalistic research on category formation in childhood has shown, however, that notions of time, space, reality, and so on go through a process of acquisition and construction that is epigenetic, mental, behavioral and linguistic. At one stroke, he claimed this "empirically refuted" both Empiricist and Rationalist epistemological theories. On the one hand, empiricist denials of an innate ability to structure experience became untenable in the face of the developmental regularities that Piaget mapped out into progressive and necessary stages. On the other hand, a rigid Apriorism he saw in Chomsky was clearly contradicted by developmental plasticity. Unfortunately, Piaget's Naturalism led him to identify Epistemology, which is normative and criteriological (or grammatical), with Developmental Cognitive Psychology, which is empirical and seeks causal explanations. From the perspective of weak foundationalism, his empirical research would not be even possible in the first place without an impure a priori conceptual framework. His empirical observations could, however, be used, not as an empirical refutation of an epistemological theory, but as a point of departure to propose its conceptual revision. Although we can never escape the web of theory, the impure a priori allows for just this kind of empirical input. Another shortcomming lies 
in Piaget's underestimation of the role of natural language in cognitive development and his adherence to Saussure. In contrast, Wittgenstein, G. $\mathrm{H}$. Mead and Vygotsky helped to move language to center stage in cognitive development as a social interaction, giving rise to the intersubjectivist paradigm (Crossley 1996).

It is important to stress that the attempt to eliminate the a priori altogether is incoherent, as it would make it impossible to distinguish between a thing and the concept we have of it (Ros 1990). Beyond bodily sensations, and even these, if we are to name them, our experience cannot be framed or interpreted without concepts and theories, nor can we have discursive knowledge. Theory is a pre-condition to structured experience, so it cannot be proven by evidence, although we may adjust our concepts or criteria to suit our cognitive interests and thus render them legitimate (not true, as this applies only to propositions). The error lies not in the concept of the a priori itself, but, as Rorty objects, in its projection into an extra-linguistic dimension, be it metaphysical, as in Plato's ideas and Aristotle's essences, or transcendental (supramental), as in Kant's categories. Taking this into consideration, Clarence I. Lewis (1923) proposed a pragmatic concept of the a priori which is not only compatible with a Wittgensteinian linguistification of Kant's impure a priori, but also, as we saw above, highly relevant in light of the epistemology of post hoc theorization of clinical experience that prevails in contemporary music therapy theory.

\section{Weak Foundationalist Critique of Neuroscience (Hacker, Ros, Reichlin)}

In addition to non-foundationalism, naturalism, understood as the attempt to use natural science to solve philosophical problems, has contributed to the neglect for normative epistemological issues such as justification. In spite of their metaphysical shortcommings, weak foundationalists have undertaken the somewhat thankless task of explaining how mind-body dualism and other mistakes can be avoided. Important contributions to this critique of conceptual confusion and nonsense in neuroscientific research were given by Ros (2005), Hacker (2009), and Reichlin (2015). The most serious errors they identified are: a) confusion between empirical and conceptual issues; b) the mereological fallacy; c) neuro-mythology; d) the contingency of neuro-imaging.

\section{Confusion between Empirical and Conceptual Issues}

From the weak foundationalist perspective, conceptual issues concern normative stipulations as to how we ought to define the use conceptual 
term 'mind,' for example. Concept possession is confirmed in third person by the speaker's ability to explain the how the conceptual term ought to be used to classify phenomena (Ros 1990). This quasi-nominalist approach treats justification as a grammatological (in the Wittgensteinian sense) clarification. Although the a priori is impure because it is negotiated in empirical speech interactions, it is primarily normative. A naturalist attempt to define concepts in an a posteriori manner cannot work because it can only make sociolinguistic findings lacking any normative claim.

\section{Mereological Fallacy}

Hacker and Ros also note that neuroscientists make the mistake of attributing abilities to the brain that are only possible for human beings to perform with their whole bodies. The mereological fallacy lies in treating a part, the brain, as the whole. By itself, the brain can be neither conscious nor self-conscious. It is the person as a whole who perceives, acts, feels, speaks as an integrated system or unit.

\section{Neuro-Mythology}

In Hacker's $(2009,47)$ own words,

...by speaking about the brain's thinking and reasoning, about one hemisphere's knowing something and not informing the other, about the brain's making decisions without the person's knowing, about rotating mental images in mental space, and so forth, neuroscientists are fostering a form of mystification and cultivating a neuro-mythology that are altogether deplorable (Hacker 2009, 47).

\section{Contingency of Neuro-imaging}

Reichlin (2015) raises doubts concerning the reliability of neuroimaging as a kind of mind reading. Even when it is possible to establish a correlation between mental processes and brain activity in an individual, it remains probabilistic, lacks necessity and even bi-uniqueness. Different subjects, or even the same subject throughout the day, may use different brain areas to perform the same mental tasks. Signs of brain activation may be interpreted in several ways at the same time. This variability in brain functioning compromises any legitimate ability by authorities to take preemptive action against individuals based solely on neuro-imaging. 


\section{Impure A Priori Justification of Moral Concepts}

The attempt to justify, ground or provide a foundation for clinical recommendations depends primarily upon the status of the concepts or criteria they contain, such as the concepts of health, brain injury, rehabilitation, and musical therapeutic effects. These recommendations emerge from a conceptualization of therapeutic reality that could not, even for Kant, be deduced purely a priori. Weak foundationalist intersubjectivism proposes that the concept of human dignity ought to be present before we engage in any neurohabilitation practice as a normative guideline. The hybrid character of the impure a priori means that, on the one hand, as an innate cognitive framing capacity, it structures our sensory experience, while on the other hand its distinctions adjust to knowers' needs and interests, much like Kant's empirical concepts. It is true, however, that none of these recommendations can claim the status of categorical imperatives, but remain only hypothetical maxims, in keeping with a prudential view expected of health and social services. The act of justifying is, from the Wittgensteinian perspective, a speech-act such as a promise or a plea. As it appeals to a potentially shared interest in cooperating towards a future moral consensus, it operates in the realm of rhetoric and does not, as Rorty believes, assume or require a pre-given truth. Neither is it vitiated by circularity as Rorty claims, as a circle only occurs between propositions, not between speech-acts (Ros 1990). Much like Habermas' idealcommunicative rationalism, weak foundationalism places its hope in uncoerced communication and the preservation of ethnic lifeworlds from instrumental rationality pushed by global oligarchies. By negotiating our differences in civil discourse, and by pondering the pros and cons of available alternatives, freedom, choice, responsibility, and the establishment of legitimate norms and laws all become possible. The foundation of obligatory deontic force of any moral judgment or norm can then be said to lie in previous intersubjective consent.

\section{On the Intrasubjectivist Approach in Hermetic Moral Metaphysics}

The intersubjectivist paradigm has made it possible to overcome the foundational void that post-modern skepticism, cynicism, and nihilism would seem to condemn us to. Regrettably, however, by remaining a somewhat neglected academic theory, it has not been able to fight back a massive wave of irrationality, hostility and negativity in the wider culture that, consciously or not, marketers, journalists, bloggers and other social media actors have promoted over the last decade or so, such as conspiracy 
theories and fake news. This open disinformation war uses techniques of cognitive dissonance and gaslighting to achieve the opposite of Habermas' ideal public sphere. In such a situation, the individual is compelled to look inward, as the conditions for fruitful intersubjective exchange become more and more compromised. At the same time, social conflict is intensified by placing emphasis on external group traits that are beyond the individual's choice or control (sex, race, etc.). Narratives are fabricated to blame or defame the Other, nurture past grudges, to justify eternal hatred, and to reject reasoned dialogue. In this unfortunate context, Moral Anthropology understood as an interdisciplinary alliance between Philosophy and Anthropology could play a helpful role, at least in the academic world. In this regard, two issues are particularly important to clarify. The first concerns a recovery of the concept of the impure a priori in human sciences such as Anthropology, Psychology or Sociology. The second addresses the perceived lack of metaphysical depth in the intersubjectivist paradigm by exploring intrasubjectivity.

\section{The Impure A Priori in Moral Anthropology}

From the weak foundationalist perspective, Philosophy (in particular, Epistemology and Meta-Ethics) is concerned with conceptual issues that need to be defined before any empirical investigation can be even undertaken. At this level of pre-conceptualization or framing of reality, Philosophy is understood as a Criteriology (theoretical investigation of criteria) or a Grammatology (mapping of terminological grammar as in Wittgenstein's later approach). For example, without definite criteria for the attribution of a type of cognitive state or skill, cognitive psychologists cannot make reliable observations. Naturalization cannot remedy this by "observing the observer" because even the meta-observers need to frame their observations conceptually. Perception cannot substitute for conceptual reflection. Regrettably, naturalism has become such a widespread epistemological error that it is unlikely to go away any time soon.

Didier Fassin, one of the major promoters of Moral Anthropology, not being a philosopher, but rather an anthropologist, understandably prefers to avoid committing himself to specific definitions of terms such as 'morals', 'morality', 'ethics', 'values' and so on. He justifies this lack of definitions by acknowledging the historical diversity of philosophical opinions and the inductive method used by most social scientists. Kirsten Bell (2018) justifiably takes him to task for this. She also objects that, although Moral Anthropology disavows any normative position, it cannot avoid taking one 
regarding its choice of subject, morality. In doing this, Moral Anthropology becomes just another kind of moral discourse, not an objective science dealing with facts and causal explanations. In addition, it fails to convince us that its values are a priori moral. Kwame Anthony Appiah (2015) admits that the experience of historical and anthropological diversity has led philosophers as different as Nietzsche, Wittgenstein and Quine to regard truth as a culturally relative criterion. In his view, Anthropology can help ethical theorists to become more aware of variations in human behavior, particularly when they investigate moral principles by a priori reasoning. However, in spite of these critical efforts, confusion still reigns concerning the possibility to avoid the a priori altogether. The delusion persists that doing this could somehow provide direct (that is, unmediated by mind or language), objective knowledge of reality.

Part of the problem lies in the fact that the watershed moment in which Kant's a priori Moral Metaphysics was challenged by Herder's a posteriori Moral Anthropology took place over 200 years ago (Zammito 2002). The reception of Kant's critical philosophy was hindered by uncertainty regarding the priority or not of the a priori-a posteriori distinction over the analytic-synthetic distinction (Ros 1991). Herder rejected the very concept of Kant's a priori categories and insisted that all mental content had to be acquired via the body (Sikka 2013). The dominant Epistemology in contemporary Science can be fairly described as Empiricistor Positivist-inspired Realism. This creates a blind spot in the foundations because concepts are assumed to derive causally (the issue of origin) and to be rationally justified (the issue of legitimacy) by sensory experience. Theories are believed to be proven by evidence. The Kantian notion that sensory and perceptual experience needs to be framed beforehand by concepts and criteria to be even possible at all is rather unfamiliar (except in experimental design) and apparently generates unease in some scientists. Herder's empirical, analogical, interpretative, and qualitative approach has, because of its fecundity and success, elevated his own insights on a linguistic a priori into a central tenet of post-Wittgensteinian weak foundationalism. As Sikka $(2013,193)$ puts it: "Herder espouses a brand of empiricism for which the "given" consists not of immediate and neutral sense data, but of experiences shaped by specifically human powers and interests, and already conditioned by the complex and shifting a priori of language." Indeed, with proper care in differentiating between the impure a priori and the a posteriori, it is possible to keep the best of both Kant and Herder, reconnect with the most interesting $20^{\text {th }}$ century contributions of Piaget, G.H. Mead, Vygotsky, Wittgenstein, Chomsky, Habermas, and M. A. K. Halliday, while avoiding the misunderstanding generated by Naturalism 
and reductive Materialism that lead to misguided foundational expectations in Moral Anthropology.

Regarding the bioethics of music therapy, while on the one hand workers in health and social care face enormous practical challenges in the concrete material world, ethicists on the other hand struggle to provide arguments that are sufficiently convincing to build an uncoerced consensus for future social integration and solidarity (Habermas). The progressive systemic differentiation of health and social care systems may lead to autonomous decision making that answers only to functional criteria such as maximizing patients' recovery and discharge from the hospital. Under such conditions, ethical notions such as humane treatment are bound to be approached from the perspective of instrumental reason, in which a Kantian view of persons as ends in themselves will take second place to Utilitarian considerations defined by oligarchic interests. The ideal of an individual who can exercise an autonomous will in accordance with a universal, necessary, objective and pure practical reason is noble indeed, but has failed, over the last 300 years, to become socially and culturally viable. In the current ethnically charged political climate, it must face radicalized social movements that nurture a collectivist animus against individual autonomy. Kant's Moral Metaphysics would seem bound to remain a grand chapter in the history of ideas, while Herder's Moral Anthropology, in spite of its ambiguities, would seem vindicated in its affirmation of social situatedness, mental embodiment and natural language. However, a proper intermediate position between Kant and Herder can and should be worked out.

Resistance to the technocratic colonization of the lifeworld (Habermas) shall require argumentative strategies that explore the moral resources of local traditions and the allegiance to their strong values (Charles Taylor). These are perhaps best expressed by musical lifeworlds such as the blues for African-Americans, flamenco for South Europeans and other Mediterranean peoples, Celtic and folk music for North Europeans. Historically, the ancient Greek notion of mousikê, with its union of dance, song and poetry, provided the basis for Dionysian psychosomatic integration. In addition to Pythagoras' mathematization of music, Damon's ethos theory reinforced Plato's educational policy. Ethnomusicology has shown the wealth and complexity of musical traditions around the world, as they play a central symbolic role in religious, spiritual, and other social practices. However, much like the attempt to impose top-down global laws and rules, the development of world music and fusion styles cannot succeed if it does not resonate with the public. On the contrary, the deep emotional, linguistic and religious bonds of local musical traditions are irreplaceable 
and should be maintained. Hopefully, Herder's vision of a humanitarian quest for mutual understanding and a cooperative development of legitimate concepts of morality, music, song, and therapy will find more support as it becomes better known.

Intrasubjectivist Exploration of Metaphysical Depth and Holistic Music Therapy

While the intersubjectivist approach succeeds in providing a weak foundation for moral concepts as legitimate proposals for a future society, it lacks metaphysical depth. For this reason, it is often dismissed as superficial. Pellegrino $(2006,251)$ seeks to refute $20^{\text {th }}$ century rejection of foundationalism and metaphysics by claiming that any philosophical position will inevitably harbor metaphysical moral commitments. Unfortunately, this rather conventional argument depends on a dogmatic projection on our part. We run the risk of being unfair or plain wrong as we read commitments into our opponent's disclaimer. Charles Taylor (2012) offers a better alternative by arguing that human natural languages enable us to present to one another claims to strong values that establish existential meaning in a moral context. He reminds us that language has other expressive dimensions that are missed if we reductively conceive it as a referential code for scientific use. While fully cognizant of the possibilities of negotiation and justification made possible by Wittgensteinian weak foundationalism, Taylor does not relinquish the exploration of intraindividual sources in the self.

The intrasubjective perspective generally runs the risk of being dismissed by mainstream scientific Psychology and Philosophy unless it can produce intersubjectively shared content. In contrast, C. G. Jung's Analytical Psychology provided concepts, theories and hypotheses which were indispensable for what came to be known as the transpersonal approach, in which religion and spirituality can be taken seriously, and not just misrepresented as delusions. Hitchcock (1987) relates how music therapists Margaret Tilly and Mary Priestley developed different approaches to explore the unconscious based on Jung's ideas. For intrasubjective development to be possible, the ancient Gnostic notion of immanent transcendence is necessary. In principle, individuals can, with adequate preparation and alignment of parts, access deeper reality beyond themselves, giving rise to transpersonality. Traditionally, music has played a significant role in shamanistic and other spiritual practices up to this day. Individuals with Jung's (1971) dominant introverted cognitive functions as well as Chestnut's (2013) Enneagram types 4 and 5 may be more responsive than others, who are more extraverted. 
Among the early $20^{\text {th }}$ century pioneers of music therapy, besides the previously mentioned F. K. Harford, Rudolf Steiner developed Eurythmy with Marie von Sivers with educational but also therapeutic purposes. His Anthroposophy has not yet been brought in line with mainstream scientific standards, but has nevertheless provided inspiration. For example, Helen M. Tyler (Horden 2000) mentions that Steiner's concept of the astral body, which would musically connect the individual to the cosmos, was used by Nordoff and Robbins as a basis for their concept of innate individual musicality ("the music child").

In reviewing the history of Pythagorean, Hermetic and Paracelsian therapeutic conceptions, Manly Palmer Hall (2003) makes an important point concerning the uselessness of purely materialistic interventions if the underlying cause can somehow be conceptualized as being spiritual. This observation cannot be properly addressed here, but follows from a radical reconceptualization of how matter and spirit causally interact in the person as a self-reflective system. Arguing from the perspective of ancient Alexandrian Neo-Platonism, Hall (1984) defends, instead of intellectualist moral autonomy of the Kantian type, a heteronomous inner-transcendent experience of sacred meaning which is not unrelated to what German social theorist Hans Joas (2000) describes in terms of being in the grip of values (in German, Ergriffensein). Hermetic wisdom requires a strenuous effort of bodily transmutation towards rebirth on an ethereal plane (Hall 1982). Mystical experience defies literal description and can only be alluded to indirectly in metaphors, analogies and allegories. This, however, would require moving on to metaphysical poetry and leaving behind the sphere of deductive argumentation.

David Aldridge $(2000,38)$ has also defended spirituality in music therapy as a quest for transcendence:

As a process, transcendence is seen as taking us beyond our small selves, outside the everyday limitations of personality. In a step beyond egocentricty, rejecting narcissism, we take an enlightened interest in others and the world through which we are led to a greater knowledge and a capacity to love (Aldridge 2000, 47).

He also expresses concern that "... a postmodern emphasis on the glorified liberated self ... promotes extreme individuality blind to the cultural nexus in which the individual finds herself..." (Aldridge 2000, 47). 
The significance of the scientific confirmation that music can have therapeutic value in a medical context has yet to be adequately appreciated in its whole potential, including the spiritual. We can say that the intrasubjective domain touches on the innermost frontier of medical research. Even if immanent transcendence remains a controversial notion, it is at the core of spirituality (or transpersonality). The need for spiritual experience seems to be hardwired in us by evolution. And if, as Aldridge notes, some patients feel that it belongs in the therapeutic process, refusing to address it raises ethical issues in and of itself.

\section{Concluding Remarks}

The human need for existential meaning and musical relief is often looked down upon by academic philosophers and composers respectively. In the midst of a catastrophic global pandemic, in which universities have come under increasing pressure to make themselves useful, a change of attitude may be in order. Music Therapy, in spite of its ancient and honorable origins, deserves more attention and recognition for its effectiveness. And Bioethics too, if it acknowledges patients' spiritual needs, can contribute to a more self-critical understanding of MT's many applications in neurorehabilitation.

\section{Notes}

${ }^{1}$ Assistant Professor at Universidade Estadual de Campinas (UNICAMP), School of Applied Sciences (Faculdade de Ciências Aplicadas - FCA), Limeira, São Paulo (S.P.). ORCID-iD: $\quad$ https://orcid.org/0000-0001-6186-3836; e-mail: tristan.torriani@fca.unicamp.br 


\section{References}

Aigen, Kenneth. 2014. The Study Of Music Therapy. NY: Routledge.

Aldridge, David. 2000. Spirituality, Healing And Medicine: Return To The Silence. London: Jessica Kingsley Publishers.

Appiah, Kwame Anthony. 2015. "Moral Philosophy." In A Companion to Moral Anthropology, edited by Didier Fassin, 561-577. Malden, MA: WileyBlackwell.

Baker, Felicity, Jeanette Tamplin, and Jeanette Kennelly. 2006. Music Therapy Methods in Neurorehabilitation: A Clinician's Manual. London: J. Kingsley.

Bell, Kirsten. 2018. "Moral Anthropology and A Priori Enunciations." In Moral Anthropology: A Critique, edited by Bruce Kapferer and Marina Gold, 4956. New York, NY: Berghahn Books.

Bonde, Lars Ole. 2015. "The Current State Of Music Therapy Theory?". Nordic Journal Of Music Therapy 24 (2): 167-175. doi:10.1080/08098131.2014.987805.

Bunge, Mario. 1999. Las Ciencias Sociales En Discusión. Buenos Aires: Editorial Sudamericana.

Bunge, Mario. 2012. Filosofía Para Médicos. Barcelona: GEDISA.

Calcaterra, Rosa Maria. 2019. Contingency and Normativity: the Challenges of Richard Rorty. Leiden: Brill Rodopi.

Chestnut, Beatrice. 2013. The Complete Enneagram: 27 Paths to Greater Self-Knowledge. Berkeley, CA: She Writes Press.

Crossley, Nick. 1996. Intersubjectivity: The Fabric of Social Becoming. London: SAGE.

Davis, William B, Michael H Thaut, and Kate E Gfeller. 2008. An Introduction To Music Therapy and Practice. Silver Spring, MD: The American Music Therapy Association.

Decker-Voigt, Hans-Helmut, and Herbert Bruhn. 1994. "Selbstverständnis der Musiktherapie." In Musikpsychologie: Ein Handbuch, edited by Herbert Bruhn, Rolf Oerter, and Helmut Rösing, 405-411. Hamburg: Rowohlt Taschenbuch Verlag. 
Gilbertson, Simon, and David Aldridge. 2008. Music Therapy And Traumatic Brain Injury. London: Jessica Kingsley Publishers.

Habermas, Jürgen. 1990. Moral Consciousness and Communicative Action. Cambridge: Polity.

Hacker, P. M. S., Maxwell R. Bennett, M. R., Daniel N. Robinson, Daniel Dennett, and John Searle. 2009. Neuroscience and Philosophy: Brain, Mind, and Language. New York: Columbia University Press.

Hall, Manly P. 1982. What The Ancient Wisdom Expects Of Its Disciples. Los Angeles, Calif.: Philosophical Research Society.

Hall, Manly P. 1984. Lectures On Ancient Philosophy. Los Angeles, Calif.: Philosophical Research Society.

Hall, Manly P. 2003. The Secret Teachings Of All Ages: Reader's Edition. NY: Tarcher-Penguin.

Hardy-Vallée, Benoit. 2012. Qu'est-Ce Qu'un Concept?. Toronto: University of Toronto.

Hitchcock, Dorinda Hawk. 1987. "The Influence Of Jung's Psychology On The Therapeutic Use Of Music". Journal Of British Music Therapy 1 (2): 1721. doi: $10.1177 / 135945758700100204$.

Horden, Peregrine. 2000. Music As Medicine: The History Of Music Therapy Since Antiquity. NY: Routledge.

Joas, Hans. 2000. The Genesis Of Values. Cambridge: Polity.

Jung, Carl G. 1971. Psychological Types. London: Routledge.

Lewis, Clarence Irving. 1923. "A Pragmatic Conception Of The A Priori". The Journal Of Philosophy 20 (7): 169. doi:10.2307/2939833.

Magee, Wendy. 1999. "Music Therapy Within Brain Injury Rehabilitation: To What Extent Is Our Clinical Practice Influenced by the Search for Outcomes?" Music Therapy Perspectives 17, no. 1: 20-26. https://doi.org/10.1093/mtp/17.1.20.

Nielsen, Kai. 1993. "Skeptical Remarks On The Scope Of Philosophy: Rorty v. Habermas." Social Theory And Practice 19 (2): 117-160. doi:10.5840/soctheorpract199319210.

Pellegrino, Edmund D. 2006. "Toward a Richer Bioethics: A Conclusion." In Health and Human Flourishing: Religion, Medicine, and Moral Anthropology, 
edited by Carol R. Taylor and Roberto Dell'Oro, 247-270. Washington, D.C.: Georgetown University Press.

Piaget, Jean. 1970. A Psicologia. Lisboa: Bertrand.

Plahl, Christine. 2008. "Musiktherapie - Praxisfelder und Vorgehensweisen." In Musikpsychologie: Das Neue Handbuch, edited by Herbert Bruhn, Reinhard Kopiez, and Andreas C. Lehmann, 630-652. Reinbek bei Hamburg: Rowohlt Taschenbuch Verlag.

Reichlin, Massimo. 2015. "Neuroethics." In A Companion to Moral Anthropology, edited by Didier Fassin, 595-610. Malden, MA: WileyBlackwell.

Rorty, Richard M. 1999. Contingency, Irony, and Solidarity. Cambridge: Cambridge U.P.

Ros, Arno. 1990. Begründung Und Begriff. Hamburg: Felix Meiner Verlag.

Ros, Arno. 1991. "Kants Begriff Der Synthetischen Urteile A Priori". KantStudien 82 (2): 146-172. doi:10.1515/kant.1991.82.2.146.

Ros, Arno. 2005. Materie Und Geist: Eine Philosophische Untersuchung. Padeborn: Mentis.

Roskies, Adina. 2016. "Neuroethics". In The Stanford Encyclopedia of Philosophy (Spring Edition), edited by Edward N. Zalta. https://plato.stanford.edu/archives/spr2016/entries/neuroethics/.

Sacks, Oliver. 2018. Musicophilia: Tales of Music and the Brain. London: Picador.

Sikka, Sonia. 2013. Herder on Humanity and Cultural Difference: Enlightened Relativism. Cambridge: Cambridge University Press.

Taylor, Charles. 2012. Sources of the Self: the Making of the Modern Identity. Cambridge, MA: Harvard Univ. Press.

Tesser, Abraham, and Norbert Schwartz. 2001. Blackwell Handbook Of Social Psychology: Intraindividual Processes. Malden, MA \& Oxford, UK: Blackwell Publishing Ltd.

Thaut, Michael, and Volker Hömberg. 2014. Handbook Of Neurologic Music Therapy. Oxford: Oxford University Press. 
Zammito, John H. 2002. Kant, Herder, And The Birth of Anthropology. Chicago: University of Chicago Press.

Received/Recebido: 20/02/21 Approved/Aprovado: 02/04/21 